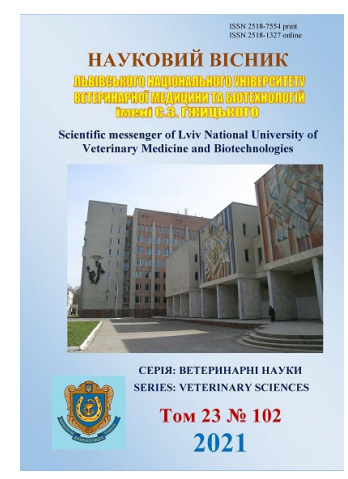

Науковий вісник Яьвівського національного університету ветеринарної медицини та біотехнологій імені С.3. Гжицького. Серія: Ветеринарні науки

\author{
Scientific Messenger of Lviv National University \\ of Veterinary Medicine and Biotechnologies. \\ Series: Veterinary sciences
}

UDC 619:616.1/9-07-056.76-08:614.2.07.066.1:636.1

\title{
Prevalence of gastric ulcer syndrome in horses with different exercise intensity
}

\author{
O. Stefanyk, L. Slivinska
}

Stepan Gzhytskyi National University of Veterinary Medicine and Biotechnologies, Lviv, Ukraine

Article info

Received 24.03.2021

Received in revised form 26.04.2021

Accepted 27.04.2021

Stepan Gzhytskyi National University of Veterinary Medicine and Biotechnologies Lviv, Pekarska Str., 50, Lviv, 79010, Ukraine. Tel.: +38-063-197-29-03 E-mail: ostapstefanyk@gmail.com
Stefanyk, O., \& Slivinska, L. (2021). Prevalence of gastric ulcer syndrome in horses with different exercise intensity. Scientific Messenger of Lviv National University of Veterinary Medicine and Biotechnologies. Series: Veterinary sciences, 23(102), 72-77. doi: 10.32718/nvlvet10211

Gastric ulcers or equine gastric ulcer syndrome (EGUS) is a common pathology in horses of different breeds. The objective of our research work was to investigate and determine the prevalence and severity of equine gastric ulcer syndrome (EGUS) in population of $n=28$ riding horses with periods of physical activity and training intensity. Two breeds were presented in this study: English Thoroughbred $(n=15)$ and Ukrainian riding horse $(n=13)$. Horses were two age groups 3-7 and 8-16 years, including 17 mares and 11 geldings. Gastric endoscopy was performed as a diagnostic tool using a $3 \mathrm{~m}$ video endoscope. Mucosal defects was evaluated using grading system proposed by (Equine Gastric Ulcer Council 0-4 grading system) ranging from 0 (normal mucosa with no lesions) to 4 (diffuse ulceration of mucosa with deep lesions). The study was conducted in two periods. Each period is related to different workload with mixed intensity in exercise during training program. The results of gastroscopic examination of the stomach indicate the prevalence of EGUS in $35.7 \%$ during the first stage in horses with mild training. The severity of mucosal defect during this period which were related to grade 1 was shown in $10.7 \%$ of horses, $2-$ $21.4 \%, 3-10.7 \%$ and $4-0 \%$. Difference in results was found in the presence and severity of gastric ulcers between two periods in this study. During period of intermediate training the prevalence of EGUS was $46.4 \%$ with severity of mucosal defect grade 1 presented in $14.2 \%$ of affected horses, $2-28.5 \%, 3-$ $14.2 \%$ and $4-3.5 \%$. Ulcerations on squamous gastric mucosa was diagnosed more often during each period (35.7 - 50\%) compare to glandular $(7.1-10.7 \%)$. The study confirms association between training intensity and gastric ulceration in two breed of horses. The prevalence and severity is dependent of the training intensity.

Key words: Gastric ulceration, prevalence, training, horse, endoscopy, stomach.

\section{Вплив інтенсивності фізичного навантаження на поширеність синдрому виразки шлунка у верхових порід коней}

\author{
О. В. Стефаник, Л. Г. Слівінська
}

Львівський національний університет ветеринарної медицини та біотехнологій імені С. 3. Гжсицького, м. Львів, Украӥна

Синдром виразки илунка, або Equіne gastric ulcer syndrome (EGUS), є поширеною патологією у верхових порід коней. У статті наведені результати досліджень щодо поширеності уражень слизових оболонок шлунка у двох порід коней: англійської чистокровної $(n=15)$ та української верхової $(n=13)$. Дослідження проводили методом візуальної оиінки стану слизових оболонок шлунка 3 використанням гастроскопа довжиною 3 м. Для оиінки та опису виявлених уражених ділянок на слизових оболонках стінки шлунка використовували ступеневу систему класифікації (Equine Gastric Ulcer Council 0-4 grading system). Дослідження проводились у два етапи, з різною інтенсивністю фізичних навантажень. Результати гастроскопічного дослідження шлунка вказують на поширеність EGUS y 35,7 \% коней перед початком періоду інтенсивного тренінгу. Отримані дані першого етапу досліджень вказують на ураження слизових оболонок шлунка 1 ступеня - у 10,7 \% коней, 2 - 21,4\%, 3 - 10,7 \% та 4 - 0 \% тварин. За збільшення частоти та інтенсивності під час тренувань у період підготовки до локальних змагань (другий етап досліджень) поширеність становить 46,4\%. Діагностовано місия ульиераиії слизової оболонки илунка верхових порід коней відповідно до ступеня ураження: 1 - 
14,2\%; 2 - 28,5\%; 3 - 14,2\%; 4 - 3,5\%. Найчастіше ураження слизової оболонки шлунка візуалізувалися на незалозистому відділі в ділянці малої кривизни поряд з межею таrgo plicatus. Дефекти слизової оболонки шлунка діагностувалися частіше на стінках незалозистого відділу (35,7 - 50 \%), ніж залозистого (7,1 - 10,7 \%). Отримані результати проведених досліджень вказують на взаємозв'язок між збільшенням інтенсивності під час фізичних навантажень та частотою уражень слизової оболонки илунка в англійської чистокровної та української верхової породи. Встановлена дещо вища частота уражень стінок СОШ в англійської чистокровної породи (66,6\%) порівняно з украӥнською верховою породою, де поширеність EGUS cтановила 53,8 \%.

Ключові слова: виразка, ерозія, илунок, ендоскопія, кінь, поширеність.

\section{ВстуII}

У структурі хвороб шлунково-кишкового тракту виразкова хвороба шлунка є поширеною і часто діагностується серед коней різних порід (Sandin et al., 2002; Bell et al., 2007; Habershon-Btucher et al., 2012). До факторів ризику виникнення виразкової хвороби шлунка у коней належать активний тренінг та інтенсивне фізичне навантаження (кінні спортивні заходи та змагання, робота), а також незадовільні умови утримання, годівля, транспортування (Vatistas et al., 1999; Nadeau et al., 2000; Husted et al., 2008; Luthersson et al., 2009). На основі аналізу зарубіжних літературних джерел (Jonsson \& Egenvall, 2006; Bell et al 2007; Tamzali et al 2011), де об'єктом досліджень були шлунки коней, варто зазначити, що поширеність виразок слизових оболонок шлунка (СОШ) серед різних порід коней коливається. Це може бути пов'язано $з$ поліетіологічною природою даного захворювання. Клінічні ознаки ураження не завжди виражені, їхній прояв залежить від активності, ступеня та ділянки ульцерації. За ураження СОШ симптоми можуть проявлятися втратою апетиту, абдомінальним дискомфортом, зниженням маси тіла, погіршенням працездатності та загальної продуктивності коней (Rabuffo et al., 2002; Niedzwiedz et al., 2013).

Шлунок у коней згідно з анатомічними та функціональними особливостями складається 3 двох відділів (залозистого та незалозистого). Залозистий відділ шлунка поділяється ще на чотири частини відповідно до функції залоз, специфічних для окремих ділянок. Ураження стінок СОШ диференціюються відповідно до відділу шлунка, оскільки окремі його ділянки є більш чутливими через відсутність бар'єрної функції (Argenzio \& Eisemann, 1996). Варто зазначити, що секреторна функція шлунка у коней має певні видоспецифічні аспекти, зокрема постійну секрецію хлоридної кислоти (HCL). Даний процес відіграє важливу роль у травленні, проте може мати й негативний вплив: безперервна секреція HCL викликає подразнення СОШ, що надалі супроводжується процесами ульцерації. Механізм ураження слизової оболонки 3 утворенням виразок на стінках шлунка - це процес порушення рівноваги між факторами агресії та фактором захисту (Argenzio \& Eisemann, 1996).

У даній статті для опису виявлених патологічних ділянок ерозивного та виразкового характеру на стінках обох відділів шлунка використовується термін "Equine gastric ulcer syndrome" (EGUS), або синдром виразки шлунка коней. Термін EGUS також класифікується на групу захворювань, що обумовлені місцем локалізації патологічних змін відповідно до відділу шлунка, на захворювання незалозистого відділу -
"Equine squamous gastric disease” (ESGD) та залозистого відділу шлунка - "Equine gastric glandular disease” (EGGD). У 1999 році вперше було введено термін EGUS, що сьогодні широко використовується у ветеринарній практиці та наукових публікаціях (Sykers et al., 2015). Згадана вище класифікація та термінологія була запропонована комітетом в European College of Equine Internal Medicine (ECEIM). Згідно 3 цією класифікацією, важливою $є$ диференціація захворювання за локалізацією ураження окремих відділів шлунка (Sykers et al., 2015). ECEIM вважає, що гастроскопія - єдиний діагностичний метод за хвороб шлунка, який дозволяє оцінити СОШ включно iз пілоричним та проксимальним відділом дванадцятипалої кишки. Однак ця патологія залишається одним 3 найбільш маловивчених захворювань шлунка у коней в Україні. Не вирішено багато аспектів етіології та патогенезу за синдрому виразки шлунка, що ускладнює підходи адекватної терапії у коней.

Мета дослідження - вивчити поширення синдрому виразки шлунка та встановити зв'язок з інтенсивністю фізичного навантаження у верхових порід коней.

\section{Матеріал і методи досліджень}

Дослідження проводились у весняно-літній період у два етапи. Критерієм відбору були коні верхових порід: англійської чистокровної $(\mathrm{n}=15)$ та української верхової $(\mathrm{n}=13)$, віком понад 3 роки, що не зазнавали інтенсивних фізичних навантажень під час тренінгу та не брали участі в змаганнях протягом останніх 3 місяців. Перший етап гастроскопічного дослідження шлунка коней припав на період початку підготовки до сезону локальних змагань 3 метою поліпшення фізичних якостей та показників. Тривалість періоду становила 2-3 місяці, впродовж яких коні мали тренінг не менше 5 разів на тиждень 3 тривалістю роботи в межах 50-90 хв. Другий етап гастроскопічного дослідження шлунка коней відбувся в період травня-червня 2019 року з часовим інтервалом 55-65 діб від моменту проведення першого етапу досліджень. При дослідженні були враховані вік, стать, утримання та годівля коней. За віковими критеріями було сформовано дві групи коней $3-7(5,08 \pm 0,43)$ років $\mathrm{n}=12$ та віком 8-16 $(10,75 \pm 0,66) \mathrm{n}=16$ коней У період посиленого тренінгу коней тренували 1 раз щодня з середньою тривалістю роботи від 50 до 90 хв при стійловому утриманні.

Крім загальноклінічного дослідження коней, застосовували спеціальний діагностичний метод - гастроскопію. Для гастроскопічного дослідження 3 метою оцінки стану слизових оболонок коней на наявність 
уражених ділянок використовували портативну ендоскопічну систему Burevision VLS - 150 D Digital Video System. Гастроскопію проводили в умовах конюшні з використанням седативних препаратів детомідину та бутарфанолу у дозі 0,04 мг/кг, в/в. Дослідні коні утримувалися на голодній дієті протягом 8-12 годин перед проведенням процедури для забезпечення евакуації кормових мас з просвіту шлунка. Після введення ендоскопа проводилася візуальна оцінка стану слизових оболонок на наявність уражень стінок залозистого та незалозистого відділів шлунка. Для покращення візуалізації окремих ділянок площини із залишками кормових мас на стінках шлунка змивались дистильованою водою через робочий канал ендоскопа. Для оцінки та опису виявлених уражених ділянок на СОШ використовували ступеневу систему класифікації (Equine Gastric Ulcer Council 0-4 grading system), що включає чотири ступені ураження від 0 до 4: Ступінь 0: епітелій незмінений, слизова оболонка без гіперемії та гіперкератозу; ступінь 1: епітелій незмінений, наявні ділянки гіперемії та гіперкератозу; ступінь 2: наявні дрібні маленькі або мультифокальні ураження; ступінь 3: наявні великі поодинокі чи мультифокальні ураження або великі ділянки поверхневих уражень; ступінь 4: наявні великі глибокі виразки. У період перед проведенням досліджень тваринам не задавали фармакологічних препаратів з групи противиразкових або нестероїдних протизапальних.

\section{Результати досліджень}

Під час гастроскопічного дослідження у всіх коней була проведена оцінка обох відділів шлунка. Проте фундальний відділ (дно шлунка) не був повністю досліджений у 17,8 \% коней через наявність залишків секрету та вмісту шлунка.

За результатами гастроскопічного дослідження ураження СОШ було діагностовано у 42,8 \% коней 3 EGUS на першому етапі досліджень. Згідно з анатомічним розподілом шлунка, ураження незалозистої слизової оболонки (ESGD) на даному етапі було діагностовано у 35,7 \% коней та залозистого відділу (EGGD) в 7,1 \% коней. У 10,7 \% коней було візуалізовано потовщення кератинового шару на стінках незалозистого відділу шлунка (рис. 1a). У 32,1 \% коней ураження СОШ проявлялась у вигляді фокальних та мультифокальних ерозій, що відповідають ступеням 2-3 згідно з системою класифікації (рис. 1б). Під час проведення першого етапу досліджень виразки з глибоким ураженням стінок та дифузними місцями ульцерації з пошкодженням підслизових шарів, що відповідають ступеню 4, не було візуалізовано.

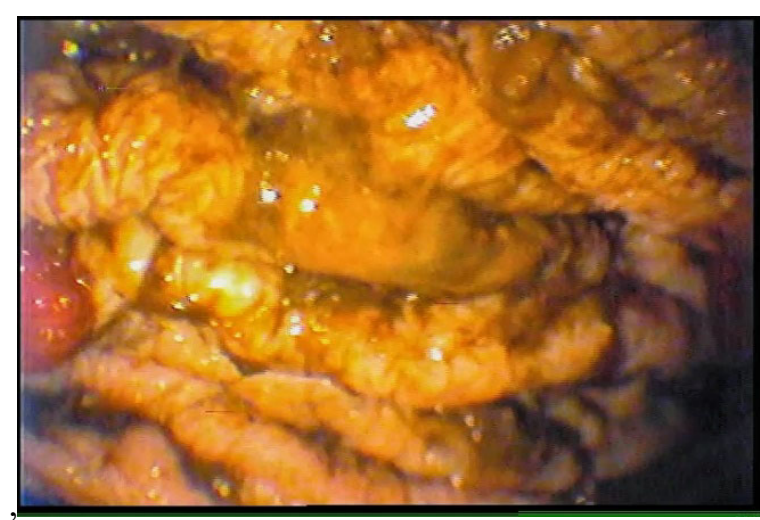

a

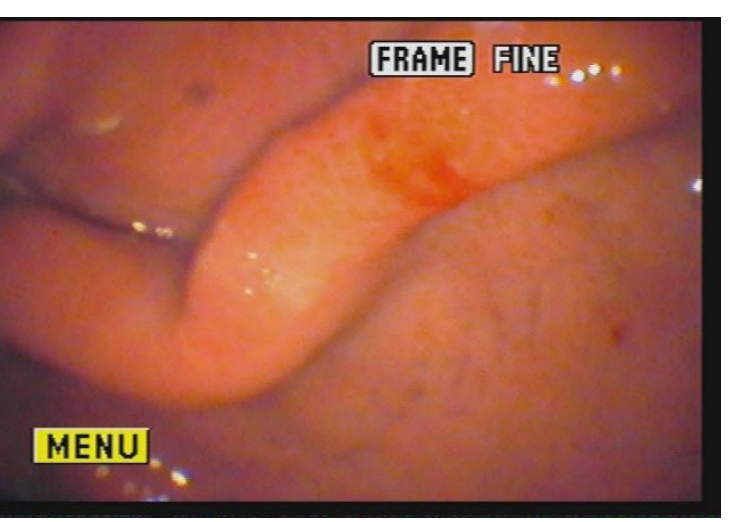

$\sigma$

Рис. 1. Ділянки гіперкератозу 1 ступеня з потовщенням кератинового шару стінки шлунка незалозистого відділу (а). 2 ступінь 3 дефектом слизової оболонки шлунка незалозистого відділу (б)

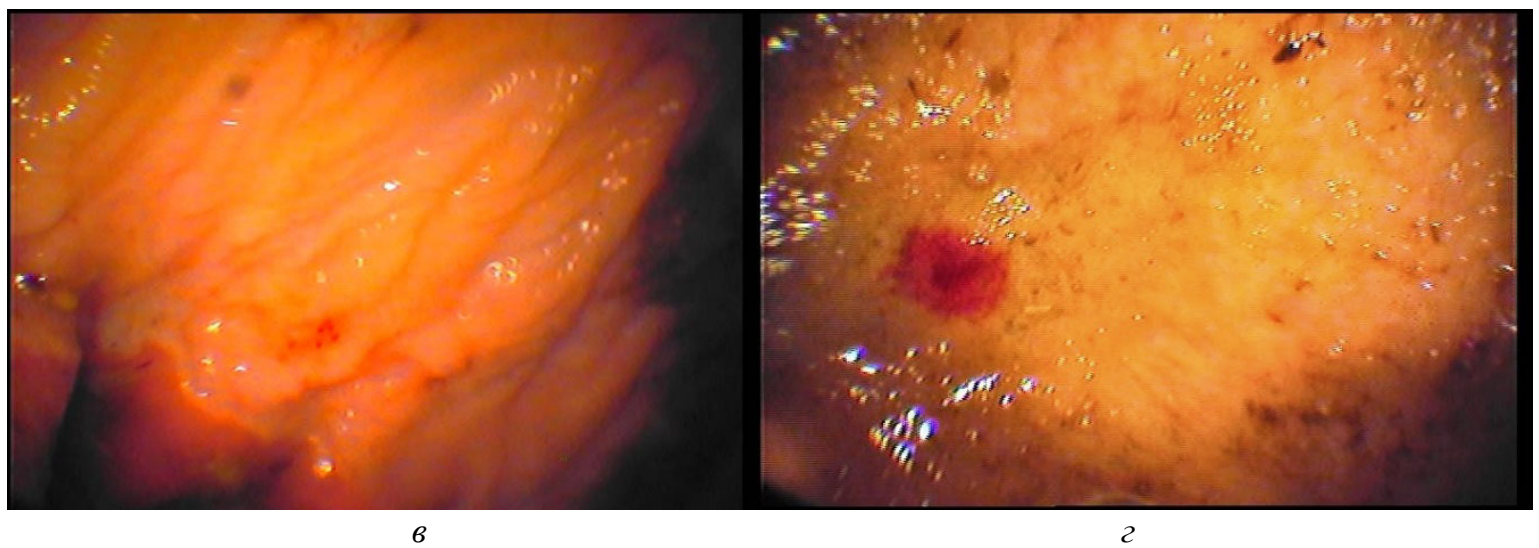

Рис. 2. Ділянка з фокальним ураженням незалозистого відділу шлунка поряд з межею margo plicatus 2 ступеня (в). Дефект стінки слизової оболонки шлунка, що відповідає ступеню 3 (г) 
Результати другого етапу проведених досліджень вказують на поширеність уражень СОШ у 60,7 \% коней, зокрема незалозистого відділу ESGD у 50 \% та залозистого EGGD у 10,7 \% коней. Під час гастроскопічного дослідження шлунка коней на другому етапі досліджень ми виявили фокальні та мультифокальні патологічні зміни 2-3 ступенів у 42,7 \% коней з патологією EGUS (рис. 2 в, г).
У 14,2 \% досліджених тварин ураження СОШ проявлялися у вигляді гіперемії та гіперкератозу, що супроводжувались потовщенням кератинового шару стінки незалозистого відділу. Локальні глибокі виразки з ураженням підслизового шару, що відповідають 4 ступеню, було діагностовано у 3,5 \% коней. Результати щодо частоти ураження стінок слизових оболонок двох відділів шлунка ESGD та EGGD у два періоди проведених досліджень наведені на рис. 3.

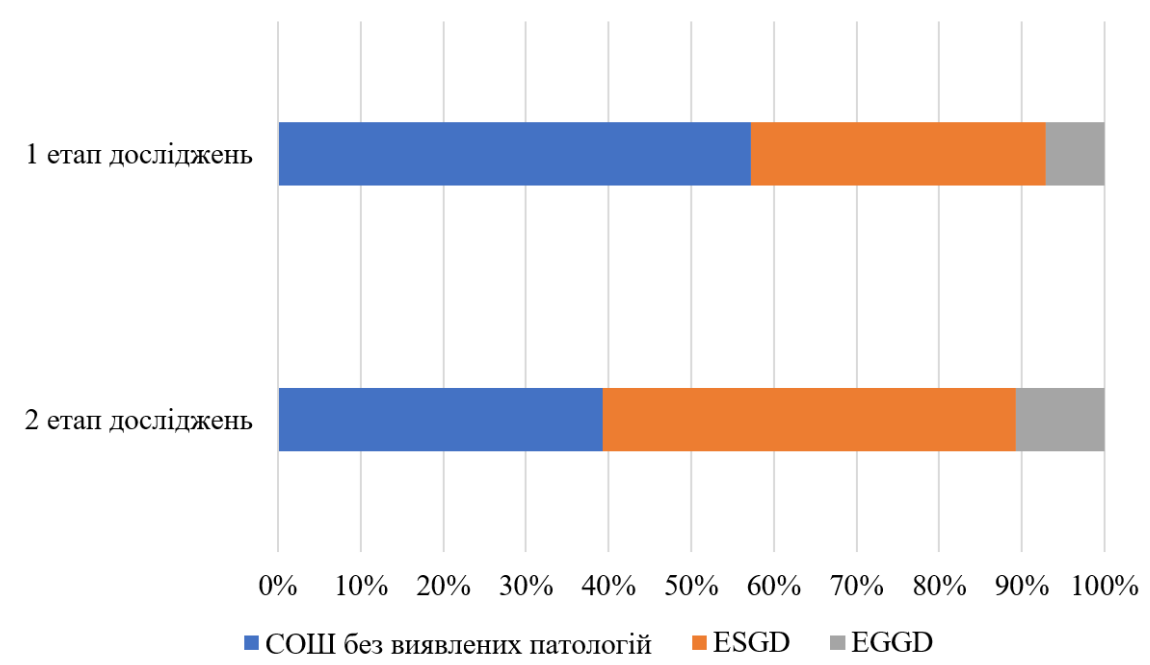

Рис. 3. Поширеність EGUS відповідно до періоду проведених досліджень

Найчастіше ділянки уражень візуалізувалися в межах малої кривизни шлунка поряд з margo plicatus (рис. 1a) на незалозистому відділі шлунка (рис. 4). У $11,7 \%$ коней ділянки ураження слизової оболонки незалозистого відділу виходили за межі margo plicatus та проявлялися у вигляді гіперемії залозистого відділу шлунка. Результати щодо тяжкості уражень стінок слизових оболонок шлунка згідно зі ступеневою системою класифікації (0-4) у два періоди проведених досліджень наведені на рис. 4.

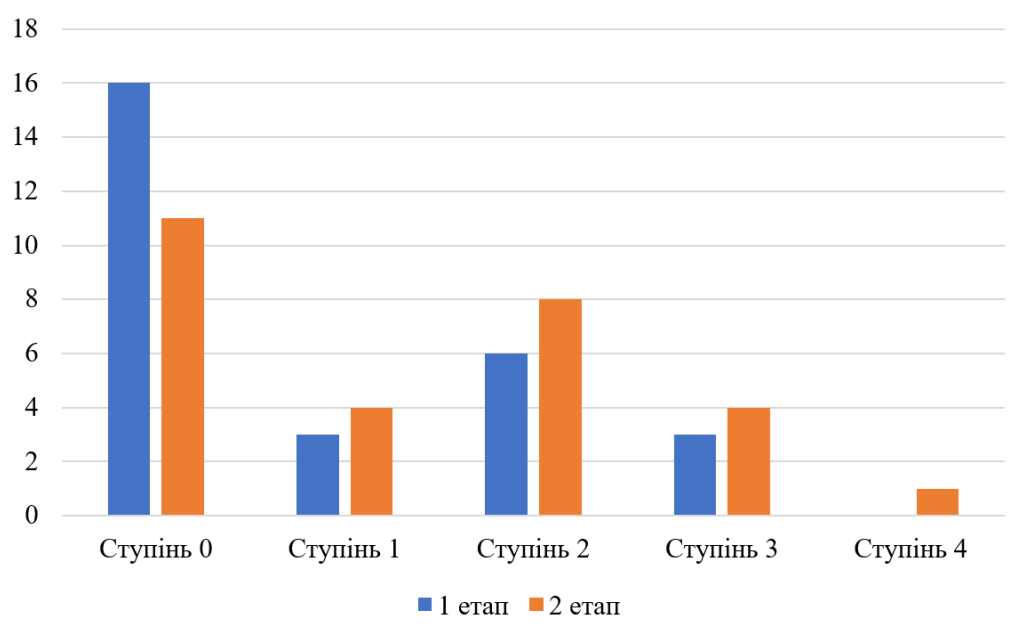

Рис. 4. Розподіл уражень стінок шлунка згідно зі ступеневою класифікацією оцінки EGUS (0-4) у два періоди досліджень

За аналізом результатів обох етапів досліджень згідно зі сформованими віковими групами виявлена вікова залежність з частотою ураження СОШ 33,4 \% у коней віком $3-7$ років $(4,5 \pm 0,65)$ та $46,8 \%$ віком 8 $16(10,71 \pm 1,02)$ років.

Ми встановили, що частота уражень СОШ в англійської чистокровної породи складала 66,6 \% і була вищою на 9,8 \% порівняно з українською верховою породою, де поширеність EGUS становила 53,8 \%.

\section{Обговорення}

За даними зарубіжних авторів (Sandin et al., 2002; McClure et al., 2005; Bell et al., 2007; HabershonButcher et al., 2012), поширеність EGUS може діагнос- 
туватися і варіювати серед різних порід коней залежно від фізичного навантаження та частоти тренінгу. Проводячи аналіз отриманих результатів після двох періодів досліджень, ми встановили поширеність EGUS в межах 42,8-60,7 \% у двох порід коней: англійської чистокровної - 66,6 \% та української верхової - 53,8 \%. Частота уражень стінок слизових оболонок шлунка в коней, що брали участь у кінних перегонах, є дещо вищою і становить 88 \% (Bell et al., 2007) порівняно з нашими результатами - 60,7\%. Іншими авторами (Tamzali et al., 2011) була встановлена поширеність ESGD у 93 \% досліджених коней, що зазнавали фізичних навантажень у забігах на довгі дистанції. Результати досліджень ряду авторів (Murray et al., 1998; McClure et al., 1999; Hartmann \& Frankemy 2003; Luthersson et al., 2009; Niedzwiedz et al., 2013) вказують на поширеність ESGD в межах $37-$ $59 \%$ у верхових коней без інтенсивного тренінгу. Варто зазначити, що поширеність патології СОШ серед різних порід коней (Murray et al., 1996; Vatistas et al., 1999; Begg et al., 2003; Habershon-Butcher et al., 2012) найчастіше діагностується в англійської чистокровної. Поширеність ESGD у даної породи складає 28-52 \% в період без активних фізичних навантажень та може сягати 80-100 \% протягом 2-3 місяців активного тренінгу. Наші дослідження виявили нижчий відсоток патології ESGD за результатами обох етапів досліджень, що становить 35,7-50 \%.

Результати гастроскопічного дослідження шлунка вказують, що частота ураження СОШ на другому етапі $є$ вищою і становить 60,7 \% порівняно з першим етапом - 42,8 \%. Отримані дані підтверджують високу ймовірність ураження слизових оболонок шлунка за збільшення інтенсивності фізичних навантажень, тренінгу, на що вказують результати другого етапу досліджень, де поширеність EGUS збільшилася на $17,8 \%$ (рис. 3 ).

Варто зазначити, що результати, отримані деякими авторами (Luthersson et al., 2009), показують, що ці фактори також можуть вказувати на варіацію результатів та поширеності EGUS серед різних порід коней. Отримані результати щодо поширеності EGUS також можуть бути наслідком таких ульцерогенних факторів, як дієта 3 високим вмістом зернових та стійлове утримання.

За результатами двох етапів досліджень, ураження СОШ залозистого відділу було діагностовано у 7,1 \% коней на першому та $10,7 \%$ - на другому етапі, що є значно нижчим результатом порівняно 3 патологією ESGD, де поширеність становила 35,7-50 \%. Відповідно до згаданих раніше особливостей шлунка, а також отриманих нами результатів можна зробити висновок, що незалозистий відділ є більш вразливим до подразнення слизових оболонок агресивним середовищем (хлоридна, жовчні кислоти) шлунка через відсутність бар'єрної функції (слиз, бікарбонат). Це також підтверджується різними науковими даними (McAllister et al., 1997; Bell et al., 2007), де ураження стінок незалозистого відділу діагностується частіше, ніж залозистого.
Отримані результати щодо ступеня тяжкості уражень слизових оболонок та їх оцінка згідно зі ступеневою системою класифікації EGUS (0-4) наведені на рис. 4. Відповідно до отриманих результатів, ураження СОШ, що відповідають ступеням 1-2, було діагностовано у $32,1 \%$ коней на першому етапі проведених досліджень та 42,7 \% на другому етапі. Ураження СОШ ступеня 3 було діагностовано у 10,7 \% коней на першому етапі та у 14,2 \% - на другому. Більш тяжкі ураження СОШ, що відповідають ступеню 4, було виявлено під час другого етапу досліджень у 3,5 \% тварин. Результати проведеної гастроскопії шлунків другого етапу досліджень вказують на утворення нових ділянок гіперемії та мультифокальних уражень слизових оболонок незалозистого відділу у 7,2 \% коней. Також виявлено негативну динаміку на місцях ульцерації стінок незалозистого відділу, що відповідає ступеню 4, у 3,5 \% коней порівняно 3 першим етапом, під час проведення якого ураження СОШ 4 ступеня не було діагностовано.

\section{Висновки}

При проведенні гастроскопії у коней верхових порід на першому етапі досліджень встановлено EGUS у $42,8 \%$ тварин 3 ураженнями стінок слизових оболонок ступенів $1-10,7 \% ; 2-21,4 \% ; 3-10,7 \% ; 4-0$. Виразки та ерозії шлунка візуалізувалися у 35,7 \% незалозистого відділу та 7,1 \% залозистого відділу. Результати повторного гастроскопічного дослідження шлунків під час другого етапу досліджень вказують на поширеність EGUS у 60,7 \% коней з ураженнями стінок слизових оболонок ступенів 1 - 14,2 \%; 2 $28,5 \% ; 3$ - 14,3\%; 4 - 3,5\%. Ураження стінок слизових оболонок незалозистого відділу на даному етапі було візуалізовано у 50 \% коней, залозистого відділу - у 10,7 \%. Результати проведених досліджень вказують на утворення нових місць ульцерацій у 17,8 \% коней. За збільшення інтенсивності та фізичної активності у період посиленого тренінгу встановлено негативну динаміку та утворення нових ділянок ульцерацій на незалозистому відділі у 14,3 \% та залозистому - у 3,5 \% коней. Діагностика виразки шлунка у коней, що базується на ендоскопічному дослідженні, дозволяє не тільки виявити захворювання, а й надати якісну оцінку його прогнозу та ефективності лікування.

Відомості про конфлікт інтересів. Автори заявляють, що не існує конфлікту інтересів.

\section{References}

Andrews, F., Bernard, W., Byars, D., Cohen, N., \& Divers, T. (1999). Anon. Recommendations for the diagnosis and treatment of equine gastric ulcer syndrome (EGUS). Equine Vet. Educ., 11(55), 262-272.

Argenzio, R., \& Eisemann, J. (1996). Mechanisms of acid injury in porcine gastroesophageal mucosa. American Journal of Veterinary Research, 57(4), 564-573. URL: https://pubmed.ncbi.nlm.nih.gov/8712526. 
Begg, L. M., \& Sullivan, C. B. (2003) The prevalence and distribution of gastric ulceration in 345 racehorses. Aust. Vet. J., 81(4), 199-201. doi: 10.1111/j.17510813.2003.tb11469.x.

Bell, R. J. W., Kingston, J. K., Mogg, T. D., \& Perkins, N. R. (2007). The prevalence of gastric ulceration in racehorses in New Zealand. New Zealand Veterinary Journal, 55(1), 13-18. doi: 10.1080/00480169.2007.36729.

Habershon-Butcher, J. L., Hallowell, G. D., Bowen, I. M., \& Sykes, B. W. (2012). Prevalence and risk factors for ulceration of the gastric glandular mucosa in Thoroughbred racehorses in training in the UK and Australia. J. Vet. Int. Mgd., 26(3), 731-731.

Hartmann, A. M., \& Frankemy, R. L. (2003). A preliminary investigation into the association between competition and gastric ulcer formation in non-racing performance horses. J. Equine Vet. Sci., 23(12), 560-561. doi: 10.1016/j.jevs.2003.11.007.

Husted, L., Sanchez, L. C., \& Olsen, S. N. (2008). Effect of paddock vs. stall housing on 24 hour gastric $\mathrm{pH}$ within the proximal and ventral equine stomach. Equine vet. J., 40(4), 337-341. doi: 10.2746/042516408X284673.

Jonsson, H., \& Egenvall, A. (2006). Prevalence of gastric ulceration in Swedish Sandardbreds in race training. Equine Vet. J., 38(3), 209-213. doi: 10.2746/ 042516406776866390.

Luthersson, N., Hou Nielsen, K., Harris, P., \& Parkin, T. (2009). Risk factors associated with equine gastric ulceration syndrome (EGUS) in 201 horses in Denmark. Equine vet. J., 41(7), 625-630. doi: 10.2746/042516409X441929.

Luthersson, N., Hou Nielsen, K., Harris, P., \& Parkin, T. (2009). The prevalence and anatomical distribution of equine gastric ulceration syndrome (EGUS) in 201 horses in Denmark. Equine Vet. J., 41(7), 619-624. doi: 10.2746/042516409x441910.

McAllister, C. G., Andrews, F., Deegan, E., Ruoff, W., \& Olovson, S. A. (1997). Scoring system for gastric ulcer in the horse. Equine Vet. J., 29(6), 430-433. doi: 10.1111/j.2042-3306.1997.tb03154.x.

McClure, S. R., Carithers, D. S., Gross, S. J., \& Murray, M. J. (2005). Gastric ulcer development in horses in a simulated show or training environmental. J. Am. Vet. Med. Ass., 227(5), 775-777. doi: 10.2460/javma.2005.227.775.

McClure, S. R., Glickman, L. T., \& Glickman, N. W. (1999). Prevalence of gastric ulcer in show horses. J. Am. Vet. Med. Ass., 215(8), 1130-1133. URL: https://pubmed.ncbi.nlm.nih.gov/10530328.

Murray, M. J. (1991). Diagnosing and treating gastric ulcers in foals and horses. Vet. Med., 8, 820-827.
Murray, M. J., Grodinsky, C., Anderson, C. W., Radue, P. F., \& Schmidt, G. R. (1998). Gastric ulcers in horses: a comparison of endoscopic findings in horses with and without clinical signs. Equine Veterinary Journal Supplement, 21(7), 68-72. doi: 10.1111/j.20423306.1989.tb05659.x.

Murray, M. J., Schusser, G. F., Pipers, F. S., \& Gross, S. J. (1996). Factors associated with gastric lesions in Thoroughbred racehorses. Equine Vet. J., 28(5), 368-374 doi: 10.1111/j.2042-3306.1996.tb03107.x.26, 731.

Nadeau, A., Frank, M. S., Andrews, M., \& Alan, G. (2000). Evaluation of diet as a cause of gastric ulcers in horses. Am. J. Vet. Res., 61(7), 784-790. doi: 10.2460/ajvr.2000.61.784.

Niedźwiedź, A., Kubiak, K., \& Nicpoń, J. (2013). Endoscopic findings of the stomach in pleaure horses in Poland. Acta Veterinaria Scandinavica, 55(1), 45. doi: 10.1186/1751-0147-55-45.

Rabuffo, T. S., Orsini, J. A., Sullivan, E., Engiles, J., Norman, T., \& Boston, R. (2002). Associations between age or sex and prevalence of gastric ulceration in Standardbred racehorses. J. Vet. Intern. Med., 19, 744-750.

Reese, R. E., \& Andrews, F. M. (2009). Nutrition and dietary management of equine gastric ulcer syndrome. Vet. Clin. Equine, 25(1), 79-92. doi: 10.1016/j/cveq.2008.11.004.

Sandin, A., Skidell, J., Haggstrom, J., \& Nilsson, G. (2002). Postmortem findings of gastric uclers in Swedish horses older than age one year: a retrospective study of 3715 horses (1924-1996). Equine vet. J., 32(1), 36-42. doi: 10.2746/042516400777612044.

Sykers, B. W., Hewetson, M., \& Hepburn, R. J. (2015). European College of Equine Internal Medicine Consensus Statement - Equine gastric ulcer syndrome in adult horses. J. Vet. Intern. Med., 29(5), 1288-1299. doi: 10.1111 jvim. 13578 .

Tamzali, Y., Marguet, C., Priymenko, N., \& Lyazri, F. (2011). Prevalence of gastric ulcer syndrome in high level endurance horses. Equine vet. J., 43(2), 141144. doi: 10.1111/j.2042-3306.2010.00129.x.

Vatistas, N. J., Sifferman, R. L., \& Holste, J. (1999). Induction and maintenance of gastric ulceration in horses in simulated race training. Equine Vet. J. Supp., 29, 4044. doi: 10.1111/j.2042-3306.1999.tb05167.x.

Vatistas, N. J., Snyder, J. R., Carlson, \& G. (1999). Crosssectional stdy of gastric ulcers of the squamous mucosa in Thoroughbred racehorses. Equine Vet. J., 31(29), 34-39. doi: 10.1111/j.2042-3306.1999.tb05166.x. 